\title{
Woody Erythematous Induration on the Posterior Neck
}

\author{
Yasser Faraj, DO; Taylor Gray, DO; Krina Chavda, DO; George Gibbons, MD; Richard Miller, DO
}

\section{Eligible for 1 MOC SA Credit From the ABD}

This Dermatopathology Diagnosis in our print edition is eligible for 1 self-assessment credit for Maintenance of Certification from the American Board of Dermatology (ABD). After completing this activity, diplomates can visit the ABD website (http://www.abderm.org) to self-report the credits under the activity title "Cutis Dermatopathology Diagnosis." You may report the credit after each activity is completed or after accumulating multiple credits.

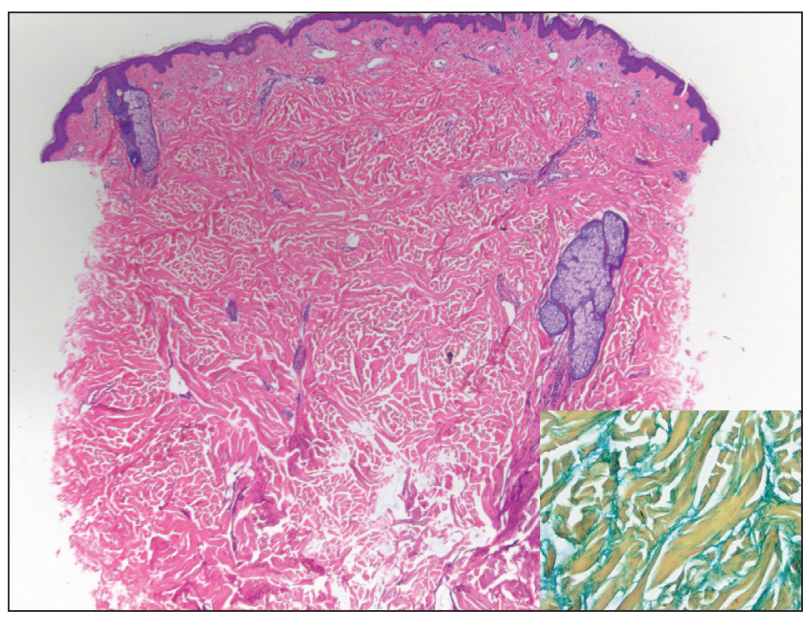

H\&E, original magnification $\times 20$ (colloidal iron, original magnification $\times 100$ [inset]).
A 39-year-old white woman with a medical history of type 1 diabetes mellitus and rheumatoid arthritis presented to the dermatology clinic with pain and thickened skin on the posterior neck of 4 weeks' duration. The patient noted stiffness in the neck and shoulders but denied any pain, pruritus, fever, chills, night sweats, fatigue, cough, dyspnea, dysphagia, weight loss, or change in appetite.

Physical examination revealed a woody indurated plaque with slight erythema that was present diffusely on the posterior neck and upper back. The patient reported that a recent complete blood cell count and complete metabolic panel performed by her primary care physician were within reference range. Hemoglobin $A_{1 C}$ was $8.6 \%$ of total hemoglobin (reference range, 4\%-7\%). A punch biopsy was performed.

\section{THE BEST DIAGNOSIS IS:}
a. pretibial myxedema
b. scleredema diabeticorum
c. scleroderma
d. scleromyxedema
e. tumid lupus erythematosus

Dr. Faraj is from Kansas City University of Medicine and Biosciences Graduate Medical Consortium, Missouri, and Advanced Dermatology and Cosmetic Surgery, Orlando Dermatology, Florida. Drs. Gray and Miller are from Largo Medical Center, Florida. Dr. Chavda is from and Dr. Miller also is from Bay Dermatology, Tampa, Florida. Dr. Gibbons is from Dermpath Diagnostics, Bay Area Dermatopathology, Tampa.

The authors report no conflict of interest.

Correspondence: Yasser Faraj, DO, 151 Southhall Ln, Ste 300, Maitland, FL 32751 (yasserfaraj92@gmail.com). 


\section{THE DIAGNOSIS:}

\section{Scleredema Diabeticorum}

$\mathrm{H}$ istologically, scleredema is characterized by mucin deposition between collagen bundles in the deep dermis. Clinically, it is characterized by a progressive indurated plaque with associated stiffness of the involved area. It most commonly presents on the posterior aspect of the neck, though it can extend to involve the shoulders and upper torso. ${ }^{1}$ Scleredema is divided into 3 subtypes based on clinical associations. Type 1 often is preceded by an infection, most commonly group A Streptococcus. This type occurs acutely and often resolves completely over a few months. ${ }^{2}$ Type 2, which has progressive onset, is associated with monoclonal gammopathy. ${ }^{3}$ Type 3 is the most common type and is associated with diabetes mellitus. A study of 484 patients with type 2 diabetes mellitus

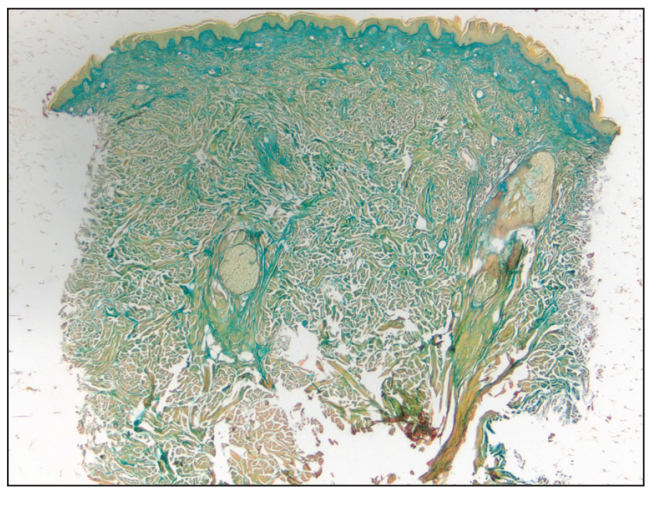

FIGURE 1. Scleredema. Colloidal iron stain highlighted dermal mucin deposition among thickened collagen bundles (original magnification $\times 20$ ).

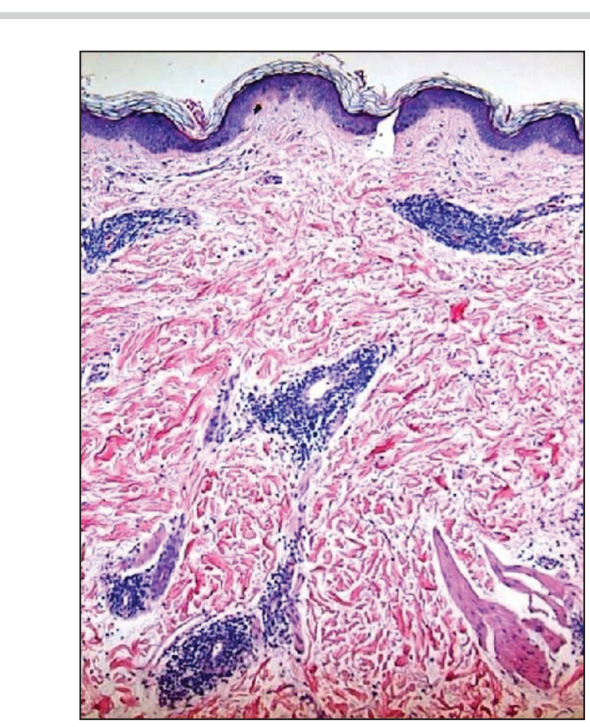

FIGURE 2. Tumid lupus erythematosus. Mucin deposition coupled with perivascular and periadnexal lymphocytic infiltration (H\&E, original magnification $\times 20$ ) demonstrated a prevalence of $2.5 \%{ }^{4}$ Although the exact pathogenesis has not been defined, it is hypothesized that irreversible glycosylation of collagen and alterations in collagenase activity may lead to accumulation of collagen and mucin in the dermis. ${ }^{5}$ Similar to type 2 , type 3 scleredema appears subtly, progresses slowly, and tends to be chronic. ${ }^{1,6}$ Scleredema is characterized by marked dermal thickening and enlarged collagen bundles separated by mucin deposition (Figure 1). Fibroblast proliferation is characteristically absent. ${ }^{1}$

Clinically, tumid lupus erythematosus presents with erythematous edematous plaques on sun-exposed areas. ${ }^{7}$ Pretibial myxedema (PM) classically is associated with Graves disease; however, it can present in association

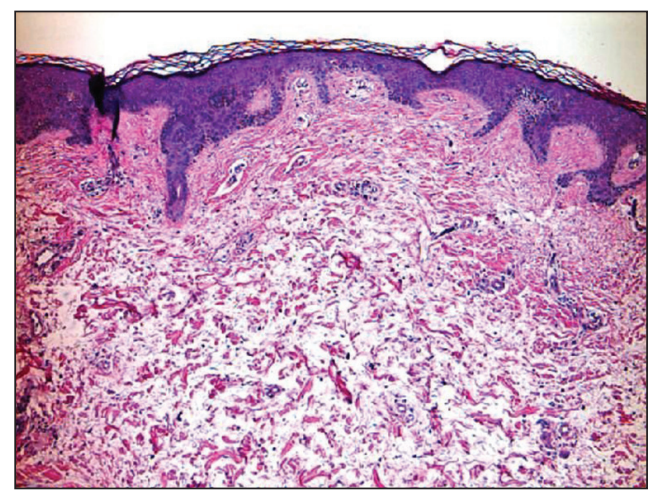

FIGURE 3. Pretibial myxedema. Mucin deposition with decreased density of collagen bundles (H\&E, original magnification $\times 20$ ).

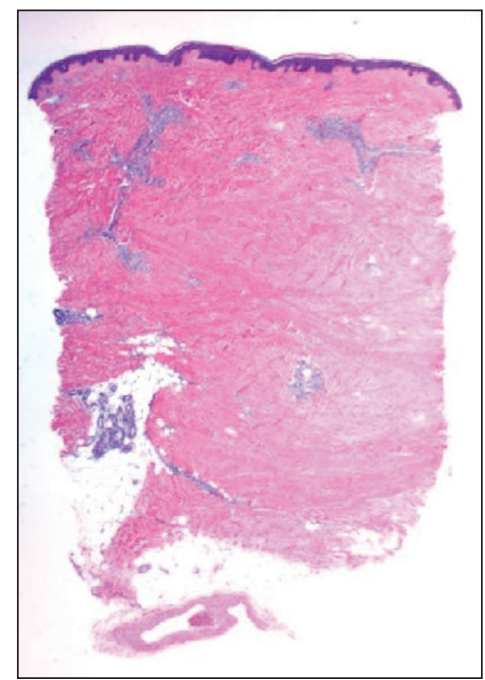

FIGURE 4. Scleroderma. Collagen bundles and the loss of intradermal fat resulted in characteristic eccrine trapping and perivascular lymphocytic infiltration (H\&E, original magnification $\times 20)$. 


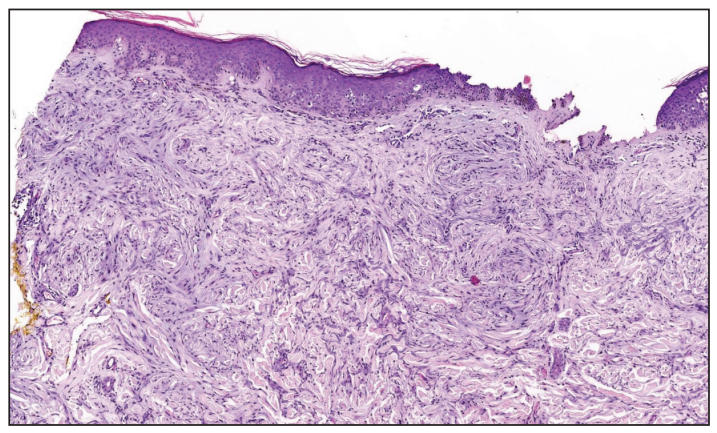

FIGURE 5. Scleromyxedema. Increased fibrocytes primarily in the superficial dermis $(H \& E$, original magnification $\times 20)$.

with other types of thyroid dysfunction. Classically, PM presents on the pretibial regions as well-demarcated erythematous or hyperpigmented plaques. ${ }^{8}$ Similar to scleredema, histologic examination of tumid lupus erythematosus and PM reveals mucin deposition. Tumid lupus erythematosus also may demonstrate periadnexal and perivascular lymphocytic inflammation (Figure 2). ${ }^{7}$ The collagen bundles present in PM often are thin in comparison to scleredema (Figure 3 ). ${ }^{8}$

Scleroderma also presents with skin induration, erythema, and stiffening. However, unlike scleredema, scleroderma commonly involves the fingers, toes, and face. It presents with symptoms of Raynaud phenomenon, painful digital nonpitting edema, perioral skin tightening, mucocutaneous telangiectasia, and calcinosis cutis. Scleroderma also can involve organs such as the lungs, heart, kidneys, and gastrointestinal tract. ${ }^{9}$ Histologically, scleroderma is characterized by a compact dermis with closely packed collagen bundles. Other features of scleroderma can include perivascular mononuclear inflammatory cell infiltration, progressive atrophy of intradermal and perieccrine fat, and fibrosis (Figure 4 ).$^{10}$
Scleromyxedema, also called papular mucinosis, is primary dermal mucinosis that often presents with waxy, dome-shaped papules that may coalesce into plaques. Similar to scleredema, scleromyxedema shows increased mucin deposition. However, scleromyxedema commonly is associated with fibroblast proliferation, which is characteristically absent in scleredema (Figure 5$).{ }^{11}$

\section{REFERENCES}

1. Beers WH, Ince A, Moore TL. Scleredema adultorum of Buschke: a case report and review of the literature. Semin Arthritis Rheum. 2006;35:355-359.

2. Cron RQ, Swetter SM. Scleredema revisited. a poststreptococcal complication. Clin Pediatr (Phila). 1994;33:606-610.

3. Kövary PM, Vakilzadeh F, Macher E, et al. Monoclonal gammopathy in scleredema. observations in three cases. Arch Dermatol. 1981;117: 536-539.

4. Cole GW, Headley J, Skowsky R. Scleredema diabeticorum: a common and distinct cutaneous manifestation of diabetes mellitus. Diabetes Care. 1983;6:189-192.

5. Namas R, Ashraf A. Scleredema of Buschke. Eur J Rheumatol. 2016; 3:191-192.

6. Knobler R, Moinzadeh P, Hunzelmann N, et al. European Dermatology Forum S1-guideline on the diagnosis and treatment of sclerosing diseases of the skin, part 2: scleromyxedema, scleredema and nephrogenic systemic fibrosis. J Eur Acad Dermatol Venereol. 2017;31:1581-1594.

7. Kuhn A, Richter-Hintz D, Oslislo C, et al. Lupus erythematosus tumidus - a neglected subset of cutaneous lupus erythematosus: report of 40 cases. Arch Dermatol. 2000;136:1033-1041.

8. Fatourechi V. Pretibial myxedema: pathophysiology and treatment options. Am J Clin Dermatol. 2005;6:295-309.

9. van den Hoogen F, Khanna D, Fransen J, et al. 2013 Classification Criteria for Systemic Sclerosis: An American College of Rheumatology/European League Against Rheumatism Collaborative Initiative. 2013;65:2737-2747.

10. Ferreli C, Gasparini G, Parodi A, et al. Cutaneous manifestations of scleroderma and scleroderma-like disorders: a comprehensive review. Clin Rev Allergy Immunol. 2017;53:306-336.

11. Rongioletti F, Merlo G, Cinotti E, et al. Scleromyxedema: a multicenter study of characteristics, comorbidities, course, and therapy in 30 patients. J Am Acad Dermatol. 2013;69:66-72. 